\title{
PEMANFAATAN LAHAN PEKARANGAN DENGAN MENERAPKAN KONSEP KAWASAN RUMAH PANGAN LESTARI
}

\author{
Dwiratna, N.P. S., ${ }^{1}$ Widyasanti, A., ${ }^{1}$ dan Rahmah, D.M. ${ }^{1}$ \\ 1) Jurusan Teknik dan Manajemen Industri Pertanian, Fakultas Teknologi Industri Pertanian, \\ Universitas Padjadjaran Jln. Raya Bandung-Sumedang Km. 21 Jatinangor \\ E-mail: sophia.dwiratna@unpad.ac.id ; asriwidyasanti@gmail.com; d.m_rahmah@gmail.com
}

\section{ABSTRAK}

Permasalahan yang dihadapi oleh masyarakat Desa Rawa dan Desa Lumbungsari Kecamatan Lumbung Kabupaten Ciamis dalam mengembangkan konsep kawasan rumah pangan lestari melalui pemanfaatan lahan pekarangan adalah kurangnya pengetahuan dan pelatihan mengenai penyiapan media tanam dalam pot, penyediaan pupuk organik dan pot atau wadah tanaman dari bahan sekitar. Tujuan dari program pengabdian masyarakat ini adalah (1) meningkatkan pengetahuan dan ketrampilan, kesadaran serta memotivasi masyarakat khususnya kelompok ibuibu rumah tangga dalam pemanfaatan lahan kosong/ pekarangan sebagai sumber pangan/ketahanan pangan dan pendapatan keluarga; (2) menerapkan beberapa teknik sederhana penanaman lahan pekarangan dan pemeliharaannya yang dapat diimplementasikan secara mudah oleh masyarakat.

Metode kegiatan yang dilakukan adalah penyuluhan, diskusi dan demonstrasi praktek langsung di lapangan yang didasari oleh evaluasi awal sebagai landasan untuk menentukan posisi pengetahuan kelompok sasaran mengenai pemanfaatan lahan pekarangan melalui penerapan konsep Kawasan Rumah Pangan Lestari.

Dari hasil kegiatan yang telah dilakukan dapat ditarik kesimpulan bahwa: (1) pada dasarnya warga masyarakat khususnya ibu-ibu rumah tangga di Desa Rawa dan Desa Lumbungsari telah menerapkan pemanfaatan lahan pekarangan, sehingga kegiatan pengabdian difokuskan pada peningkatan keterampilan ibu-ibu dalam menyiapkan media tanam untuk budidaya sayuran dalam pot, serta pemanfaatan bahan-bahan sekitar untuk pembuatan pot/wadah dan pupuk organik cair; (2) kegiatan pengabdian ini dapat menambah pengetahuan warga tentang pentingnya pemanfaatan lahan pekarangan melalui penerapan konsep rumah pangan lestari untuk mendukung ketahanan pangan keluarga.

Kata Kunci: Pekarangan, lestari, budidaya sayuran dalam pot, media tanam, pupuk organik cair

\section{ABSTRACT}

Problems faced by the community and Rawa and Lumbungsari Country Village, Lumbung Sub-District, Ciamis District in developing the concept of Kawasan Rumah Pangan Lestari through land use grounds are lack of knowledge and training on the completion of the plant in potting media, preparation of organic fertilizers and plant pots or containers from materials around. The purpose of this program is community service (1) Increase knowledge and skills, awareness and motivate people, especially mothers group home in bare land use / compound as a source of food / food security and family income; (2) Applying some simple techniques of planting yards and preservation can be implemented easily by the community. The method is carried out espionage activities, discussion and demonstration of direct practice in the field based on the initial evaluation as a basis for determining the position of the target group knowledge about the compound through the adoption of land use concept of Kawasan Rumah Pangan Lestari.

The results of the programs, showed that: (1) In principle citizens especially mothers house in the village of Rawa and Country Lumbungsari have adopted land use grounds, until service activities focused on improving skills of mothers in the completion of planting media for the cultivation of vegetables in the pot, and the utilization of materials for manufacturing around the pot / container and liquid organic fertilizer; (2) The activities of this service can increase citizen knowledge about the importance of land use through the application of the concept of home lawn food to support sustainable food security of the family.

Key Word: Garden, Pangan Lestari, Pot Cultivation, Plant Media, liquid organic fertilizer

\section{PENDAHULUAN}

Masalah ketahanan pangan nasional merupakan masalah yang harus ditangani secara bersama. Tidak hanya mengandalkan pemerintah, namun harus didukung dengan keikutsertaan secara aktif masyarakat 
dimulai dari lini terkecil pembetuk masyarakat yaitu keluarga. Oleh karenanya penguatan ketahanan pangan keluarga secara signifikan akan mampu mengatasi permasalahan ketahanan pangan secara umum. Rumah pangan merupakan salah satu konsep pemanfaatan lahan pekarangan baik di pedesaan maupun diperkotaan untuk mendukung ketahanan pangan nasional dengan memberdayakan potensi pangan lokal. Pekarangan bukan hanya untuk menciptakan keindahan dan kesejukan saja, tetapi lebih daripada itu adalah guna meningkatkan perekonomian keluarga masing-masing. Jenis-jenis tanaman yang bisa ditanam di pekarangan rumah masing-masing adalah jenis sayur-sayuran, buahbuahan, obat-obatan, tanaman hias, dan lain sebagainya yang kesemuanya itu dapat menunjang kebutuhan seharihari dan selebihnya bisa dijual. Ketersediaan pangan dalam jumlah yang cukup sepanjang waktu merupakan keniscayaan yang tidak terbantahkan. Hal ini menjadi prioritas pembangunan pertanian nasional dari waktu ke waktu. Ke depan, setiap rumah tangga diharapkan mengoptimalisasi sumberdaya yang dimiliki,termasuk pekarangan, dalam menyediakan pangan bagi keluarga.

Secara umum, permasalahan dihadapi oleh masyarakat dalam mengembangkan konsep rumah pangan lestari melalui pemanfaatan lahan pekarangan adalah kurangnya pengetahuan dan pelatihan mengenai penyiapan media tanah, penyediaan pupuk organik dari bahan sekitar dan pemanfaataan limbah dan bahan yang ada disekitar sebagai pot atau wadah tanaman.

Tujuan dari program pengabdian masyarakat ini adalah :

1. meningkatkan pengetahuan dan ketrampilan, kesadaran serta memotivasi masyarakat khususnya kelompok ibu-ibu rumah tangga dalam pemanfaatan lahan kosong/pekarangan sebagai sumber pangan/ ketahanan pangan dan pendapatan keluarga.

2. menerapkan beberapa teknik penanaman dan pemeliharaan secara sederhana yang dapat diimplementasikan secara mudah oleh masyarakat.

\section{METODE}

Sasaran penyuluhan dan pelatihan Peningkatan Ketahanan Pangan Keluarga Melalui Pemanfaatan Lahan Pekarangan dengan Menerapkan Konsep Kawasan Rumah Pangan Lestari ini adalah Kelompok ibu-ibu rumah tangga di di Desa Rawa dan Desa Lumbungsari Kecamatan Lumbung Kabupaten Ciamis.

Metode kegiatan yang akan dilakukan untuk tercapainya tujuan pengabdian kepada masyarakat ini adalah metode ceramah, diskusi dan demonstrasi praktik langsung di lapangan yang didasari oleh evaluasi awal sebagai landasan untuk menentukan posisi pengetahuan kelompok sasaran mengenai pemanfaatan lahan pekarangan melalui penerapan konsep Kawasan Rumah Pangan Lestari.

\section{HASIL DAN PEMBAHASAN}

\section{Sosialisasi dan Penjajagan Potensi}

Kegiatan pengabdian diawali dengan penjajagan ke lokasi Desa Rawa dan Desa Lumbungsari, kemudian dilanjutkan persiapan penyuluhan dan pelaksanaan pelatihan. Penjajagan ke lokasi bertujuan untuk memperoleh data mengenai kondisi pemanfaatan lahan pekarangan dan permasalahannya di kedua desa tersebut. Dari pertemuan tersebut diketahui bahwa hampir seluruh rumah di Desa Rawa dan Desa Lumbungsari memiliki potensi lahan pekarangan dengan luas beragam antara 50 $\mathrm{m}^{2}-200 \mathrm{~m}^{2}$.

Berdasarkan hasil diskusi tersebut diketahui bahwa masyarakat di Desa Rawa dan Desa Lumbungsari sebagian telah memanfaatkan lahan pekarangannya untuk kegiatan budidaya pertanian maupun perikanan, namun ada juga yang hanya memanfaatkan lahan pekarangan untuk tanaman hias dan tanaman obat-obatakan keluarga (Gambar 1).

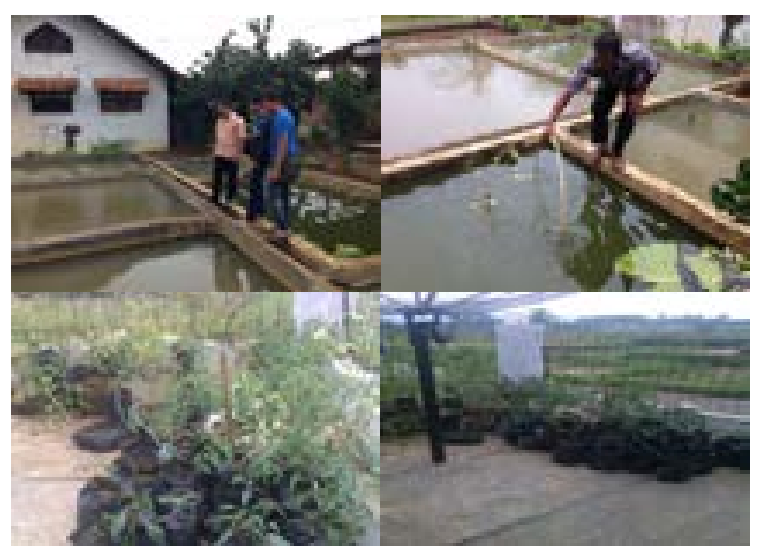

Gambar 1. Kondisi Lahan Pekarangan Existing

Masyarakat, terutama kelompok ibu-ibu yang tergabung dalam organisasi PKK sebelumnya pernah mengetahui tentang konsep pemanfaatan lahan pekarangan, namun dalam prakteknya masih memiliki beberapa kendala. Permasalahan yang umum dijumpai dalam pemanfaatan lahan pekarangan untuk budidaya tanaman dalam pot di kedua desa adalah masalah media tanam dan pemupukan. Kendala yang dihadapi adalah pada budidaya tanaman dalam pot lama-kelamaan media yang digunakan akan mengeras sehingga pertumbuhan tanaman tidak optimal, hal ini dikarenakan masyarakat hanya menggunakan tanah humus saja sebagai media tanam. Selain itu pada budidaya tanaman dalam pot kebanyakan menggunakan pot plastik yang tersedia di 
pasaran dan menggunakan polibag hitam, hal ini tentunya memerlukan biaya ekstra. Permasalahan lainnya yang dihadapi penyediaan pupuk untuk tanaman. Karena itulah dalam pertemuan pertama disepakati bahwa kegiatan pelatihan nantinya difokuskan pada pelatihan penyiapan media tanam untuk budidaya pertanian dalam pot serta pembuatan wadah/pot dan pupuk organik cair dari bahan yang ada disekitar.

\section{Kegiatan Penyuluhan dan Pelatihan}

Setelah dilakukan penjajagan, kegiatan selanjutnya yang dilakukan adalah penyuluhan dan praktik penyiapan media tanam untuk budidaya pertanian dalam pot serta pembuatan wadah/pot dan pupuk organik cair dari bahan yang ada disekitar. Kegiatan penyuluhan dan pelatihan dilakukan di Balai Desa dan dihadiri oleh kelompok ibu-ibu rumah tangga yang tergabung dalam organisasi PKK. Antusiasme ibu-ibu rumah tangga akan materi yang diberikan terlihat jelas sebagaimana ditunjukkan pada Gambar 2 berikut.

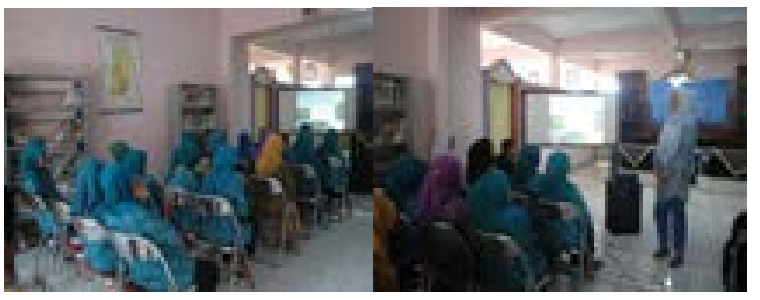

Gambar 2. Suasana Kegiatan Penyuluhan dan Pelatihan

\section{Indikator Keberhasilan Kegiatan}

Evaluasi kegiatan pengabdian dilakukan dengan cara yaitu membandingkan pengetahuan dan pemahaman warga sebelum dan sesudah kegiatan. Secara umum dapat menunjukkan bahwa terjadi peningkatan pengetahuan peserta mengenai Pemanfaatan Lahan Pekarangan dengan Menerapkan Konsep Kawasan Rumah Pangan Lestari di Desa Rawa dan Desa Lumbungsari Kecamatan Lumbung Kabupaten Ciamis. Peserta memahami bahwa pemanfaatan lahan pekarangan secara optimal dapat membantu ketahanan pangan keluarga. Pada Tabel 1 menggambarkan kriteria dan indikator keberhasilan pelaksanaan kegiatan pengabdian ini.

Strategi pemberian materi baik waktu maupun tempat terutama penyuluhan di lapangan dirasakan sangat mendukung kegiatan karena peserta mempunyai banyak waktu untuk mengikuti penyuluhan.

\section{Faktor Pendorong dan Penghambat Kegiatan}

Beberapa faktor yang dapat mendorong terlaksananya kegiatan pengabdian ini adalah peserta terutama ibu-ibu sangat bersemangat mengkoordinir acara penyuluhan. Peserta merupakan perwakilan dari tiap dusun, dan memahami mengenai pentingnya pemanfaatan lahan pekarangan melalui penerapan konsep rumah pangan lestari untuk mendukung ketahanan pangan keluarga. Selain itu yang tidak kalah penting adalah kerjasama yang baik dari pihak desa untuk mendukung dalam penyediaan sarana dan mengundang peserta sebagai perwakilan tiap dusun.

Faktor yang dapat menjadi penghambat dalam pelaksanaan pengabdian ini adalah waktu yang singkat dalam setiap materi. Sehingga tidak seluruh fasilitas dan potensi dapat ditunjukkan oleh peserta.

Tabel 1. Indikator keberhasilan kegiatan

\begin{tabular}{|c|c|c|}
\hline No & Kriteria & Indikator \\
\hline 1. & $\begin{array}{l}\text { Tingkat } \\
\text { partisipasi }\end{array}$ & $\begin{array}{l}\text { Kegiatan penyuluhan } \\
\text { selalu dihadiri peserta } \\
\text { yang jumlahnya mencapai } \\
\text { lebih dari } 20 \text { ibu-ibu rumah } \\
\text { tangga yang juga merupakan } \\
\text { perwakilan dari tiap dusun }\end{array}$ \\
\hline 2. & $\begin{array}{l}\text { Tingkat } \\
\text { Pemahaman } \\
\text { peserta } \\
\text { terhadap materi } \\
\text { penyuluhan }\end{array}$ & $\begin{array}{l}\text { Peserta aktif bertanya dan } \\
\text { sering mengemukakan } \\
\text { saran-saran serta ide-ide atau } \\
\text { pengetahuan yang mereka } \\
\text { punya serta meminta saran } \\
\text { ilmiah terhadap ide yang } \\
\text { mereka kemukakan. } \\
\text { Peserta sangat serius } \\
\text { mengikuti penyuluhan baik } \\
\text { indoor (ceramah) maupun } \\
\text { outdoor peninjauan ke } \\
\text { lapangan, bimbingan teknis. }\end{array}$ \\
\hline 3. & $\begin{array}{l}\text { Dampak } \\
\text { Penyuluhan }\end{array}$ & $\begin{array}{l}\text { Dari tahapan demi tahapan } \\
\text { penyuluhan ini terlihat } \\
\text { antusias peserta dan terlihat } \\
\text { diskusi semakin hidup } \\
\text { dan peserta menguasai } \\
\text { permasalahan yang mendasar } \\
\text { mengenai pemanfaatan } \\
\text { lahan pekarangan, penyiapan } \\
\text { media tanam untuk } \\
\text { budidaya sayuran dalam pot, } \\
\text { pembuatan pot dan pupuk } \\
\text { organik cari dari bahan sekitar }\end{array}$ \\
\hline 4. & $\begin{array}{l}\text { Kesesuaian } \\
\text { materi }\end{array}$ & $\begin{array}{l}\text { Materi penyuluhan sangat } \\
\text { relevan mengingat potensi } \\
\text { lahan pekarangan di Desa } \\
\text { Rawa dan Desa Lumbungsari } \\
\text { yang belum termanfaatkan } \\
\text { secara optimal. }\end{array}$ \\
\hline
\end{tabular}

SIMPULAN

Dari hasil kegiatan yang telah dilakukan maka dapat ditarik simpulan bahwa :

1. kegiatan pengabdian ini dapat menambah pengetahuan warga tentang pentingnya pemanfaatan lahan pekarangan melalui penerapan konsep rumah pangan lestari untuk mendukung ketahanan pangan keluarga

2. pada dasarnya warga masyarakat khususnya ibu-ibu rumah tangga di Desa Rawa dan Desa Lumbungsari telah menerapkan pemanfaatan 
lahan pekarangan, sehingga kegiatan pengabdian difokuskan pada peningkatan ketrampilan ibuibu dalam menyiapkan media tanam untuk budidaya sayuran dalam pot, serta pemanfaatan bahan-bahan sekitar untuk pembuatan pot/wadah dan pupuk organik cair.

\section{UCAPAN TERIMA KASIH}

Atas terselesainya program pengabdian ini, penulis ingin mengucapkan terimakasih kepada Lembaga Penelitian dan Pengabdian Masyarakat Universitas Padjadjaran yang telah mendanai program pengabdian "Peningkatan Ketahanan Pangan Keluarga Melalui Pemanfaatan Lahan Pekarangan Dengan Menerapkan Konsep Kawasan Rumah Pangan Lestari Di Desa Rawa Dan Desa Lumbungsari Kecamatan Lumbung Kabupaten Ciamis" ini. Tidak lupa penulis juga ingin mengucapkan terimakasih kepada seluruh kelompok ibu-ibu dan aparat desa Rawa dan Lumbungsari Kecamatan Lumbung Kabupaten Ciamis yang telah berperan aktif dalam pelaksanaan program.

\section{DAFTAR PUSTAKA}

BPTP Sulawesi Selatan. 2012. Inovasi Terkini Budidaya Sayuran di Pekarangan. Badan Penelitian dan Pengembangan Pertanian Kementrian Pertanian. Jakarta Selatan
Dwiratna, Sophia, dkk. 2012. Pembuatan Mikro Organisme Lokal (Mol) Sebagai Upaya Meningkatkan Kemandirian Petani di Desa Margajaya Kecamatan Tanjungsari Kabupaten Sumedang. Laporan Akhir Program Pengabdian Masyarakat Fakultas Teknologi Industri Pertanian Universitas Padjadjaran. Bandung

Kementerian Pertanian; SIKIP. 2012. Pengembangan Kawasan Rumah Pangan Lestari. Kementerian Pertanian. Jakarta

Mardharini, Maesti; Kariyasa, Ketut; Zakiah; Dalmadi; Susakti, Agung. 2011. Petunjuk Pelaksanaan Pengembangan Model Kawasan Rumah Pangan Lestari. Balai Besar Pengkajian dan Pengembangan Teknologi Pertanian. Badan Litbang Pertanian. Kementerian Pertanian. JakartaWarnita, dkk. 2008. Penyuluhan Dan Pemanfaatan Lahan Pekarangan Sempit Dengan Teknologi Hidroponik Dalam Rangka Meningkatkan Kesejahteraan Keluarga. Warta Pengabdian Andalas Volume XIV, Nomor 21 Desember 2008. Lampung.

Setyaningrum, Hesti Dwi, Saparinto, Cahyo. 2011. Panen Sayuran Secara Rutin di Lahan Sempit. Penebar Swadaya. Jakarta.

Soeleman, Soeparwan; Rahayu, Donor. 2013. Halaman Organik. Agromedia. Jakarta. 